\title{
Soil microbial communities following bush removal in a Namibian savanna
}

\author{
Jeffrey S. Buyer ${ }^{1}$, Anne Schmidt-Küntzel², Matti Nghikembua ${ }^{2}$, Jude E. Maul ${ }^{1}$, and Laurie Marker ${ }^{2}$ \\ ${ }^{1}$ USDA, ARS, BARC, Sustainable Agricultural Systems Laboratory, Beltsville, MD, USA \\ ${ }^{2}$ Cheetah Conservation Fund, Otjiwarongo, Namibia \\ Correspondence to: Jeffrey S. Buyer (jeffrey.buyer@ars.usda.gov)
}

Received: 2 December 2015 - Published in SOIL Discuss.: 18 December 2015

Revised: 19 February 2016 - Accepted: 4 March 2016 - Published: 9 March 2016

\begin{abstract}
Savanna ecosystems are subject to desertification and bush encroachment, which reduce the carrying capacity for wildlife and livestock. Bush thinning is a management approach that can, at least temporarily, restore grasslands and raise the grazing value of the land. In this study we examined the soil microbial communities under bush and grass in Namibia. We analyzed the soil through a chronosequence where bush was thinned at 9 , 5 , or 3 years before sampling. Soil microbial biomass, the biomass of specific taxonomic groups, and overall microbial community structure was determined by phospholipid fatty acid analysis, while the community structure of Bacteria, Archaea, and fungi was determined by multiplex terminal restriction fragment length polymorphism analysis. Soil under bush had higher $\mathrm{pH}, \mathrm{C}, \mathrm{N}$, and microbial biomass than under grass, and the microbial community structure was also altered under bush compared to grass. A major disturbance to the ecosystem, bush thinning, resulted in an altered microbial community structure compared to control plots, but the magnitude of this perturbation gradually declined with time. Community structure was primarily driven by $\mathrm{pH}, \mathrm{C}$, and $\mathrm{N}$, while vegetation type, bush thinning, and time since bush thinning were of secondary importance.
\end{abstract}

\section{Introduction}

Savanna ecosystems are defined as grassy areas with woody plants varying from widely spaced to $75 \%$ canopy (Smit, 2004). Savannas cover more than $20 \%$ of the world's land surface and include most of the world's rangelands (Riginos et al., 2009). Bush encroachment affects rangelands worldwide (O'Connor et al., 2014), while historical photographic evidence indicates that it is occurring in certain regions of Namibia (Rohde and Hoffman, 2012). Indeed, $32 \%$ of the land surface of Namibia was estimated to be affected by bush encroachment in 2004 (de Klerk, 2004). Factors controlling the density of woody plants, the temporal dynamics of woody plant density, and bush encroachment have been heavily studied but are still not completely understood. Contributing factors include herbivory, fire frequency and intensity, soil properties, rainfall, and atmospheric carbon dioxide concentrations (O'Connor et al., 2014; Bond and Midgley, 2012; Kambatuku et al., 2013; Ripple et al., 2015).
Plant communities are closely linked to soil microbial communities, with plants providing energy to most microbes through root exudates and plant litter (Lynch and Whipps, 1990; Schenck zu Schweinsberg-Mickan et al., 2012; Singh et al., 2014). In return, soil microbial communities provide critical ecosystem services, including soil formation and aggregation; plant litter degradation, humus formation, and carbon sequestration; nitrogen fixation, nitrification, and denitrification; biocontrol of pathogens; and degradation of xenobiotics (Lehman et al., 2015). The linkages between aboveground and belowground biota are poorly understood in savanna ecosystems, where dynamic changes in $\mathrm{C}_{3} / \mathrm{C}_{4}$ and leguminous/non-leguminous plant communities result in a highly complex system. However, it is clear that woody plant encroachment has the potential to alter soil microbial community biomass, structure, and diversity. Plant species composition is known to affect microbial species composition and diversity (Wardle, 2006; Maul and Drinkwater, 2010). Invasive plants have been shown to alter soil microbial com- 
munities (Batten et al., 2006), biogeochemical cycling, nutrient availability, and ecosystem function (Weidenhamer and Callaway, 2010). Soil microbial biomass has been reported to increase with increasing woody plant density and age (Liao and Boutton, 2008), while soil community composition was altered and microbial biomass increased during a reforestation experiment with Eucalyptus urophylla (Wu et al., 2013). Soil biota were altered along a desertification gradient (Klass et al., 2012). These changes in soil microbial communities have the potential to alter the rate of bush encroachment. Both positive and negative feedbacks (Wardle et al., 2004) can occur between plant and soil microbial communities, affecting the progress of plant invasion (Reinhart and Callaway, 2006; Shannon et al., 2012; Ke et al., 2015).

One technique for restoring bush-encroached savannas is to remove the woody plants, thus promoting grass growth and improving the grazing capacity of the savanna (Smit, 2004). In this study we report on a chronosequence of bush thinning. Excess Senegalia mellifera (formerly Acacia mellifera) and other woody vegetation were removed from three different plots (one plot each year) in 2003/4, 2007, and 2009, and a paired "control" plot was established adjacent to each thinned plot. We analyzed soil taken from the bush and grass environments for soil chemistry, microbial biomass, and microbial community structure in order to test the following hypotheses: (1) in a savanna ecosystem soil microbial community structure is different under grass than under woody plants, and (2) the soil microbial community is resilient to the disturbance caused by bush thinning. Soil microbial biomass, the biomass of individual taxonomic groups, and soil microbial community structure were measured by phospholipid fatty acid (PLFA) analysis. A more detailed analysis of bacterial, archaeal, and fungal community structure was provided by terminal restriction fragment length polymorphism (TRFLP) analysis of soil DNA.

\section{Materials and methods}

\subsection{Site description}

All samples were taken from the Elandsvreugde farm at the Cheetah Conservation Fund International Research and Education Centre, Otjiwarongo, Namibia (Fig. 1). The Elandsvreugde farm $\left(20^{\circ} 25^{\prime} \mathrm{S}, 17^{\circ} 4^{\prime} \mathrm{E}\right)$ is 7300 ha in size. Soils are classified as Chromic Cambisols based on a soil atlas (http://spatial-web.nmsu.edu/flexviewers/ NamibiaSpatialData/). The vegetation is characterized as thornbush savanna, with woody species such as Senegalia mellifera (Acacia mellifera) predominating. Understory vegetation is sparse except for forbs, which are briefly present following rainfall. The major grass species is hairyflower lovegrass (Eragrostis trichophora). The area receives an average annual rainfall of $400-500 \mathrm{~mm}$, thus classifying it as a semi-arid zone. The wet-hot season is January to April, followed by a dry-cold season from May to Au-

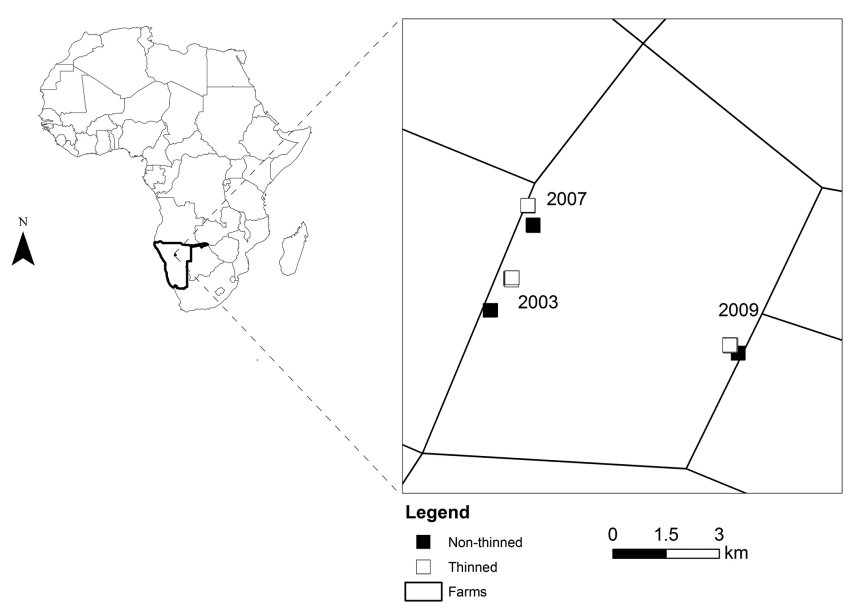

Figure 1. Map of study area.

gust, with September to December intermediate. The vegetation is utilized by wild game, including kudu (Tragelaphus strepsiceros), oryx (Oryx gazella), red hartebeest (Alcelaphus buselaphus subsp. caama), eland (Tragelaphus oryx), warthog (Phacochoerus africanus), steenbok (Raphicerus campestris), and duiker (Sylvicapra grimmia).

\subsection{Experimental treatments}

In 2003-2004 (approximate dates 15 November 2003-28 February 2004), 2007 (2-22 February), and 2009 (1 August 2009-31 January 2010) three plots (one each year) were thinned of excess Senegalia mellifera and other bushy species. Each plot was thinned once. The sizes of the thinned plots were 25, 21, and 20 ha, respectively. A control plot adjacent to and similar in size to each thinned plot was not thinned. Samples were taken from both the thinned plots and the control plots at three sampling times starting in 2012, so the plots are referred to as 9-year (bush thinned in 2003), 5 -year (bush thinned in 2007), or 3-year (bush thinned in 2009) plots. In the thinned plots bush density was reduced up to $70 \%$, almost entirely by manual cutting, while a small amount of thinning was accomplished using a hydraulic cutterhead. Tree and shrubs were cut aboveground $( \pm 30 \mathrm{~cm})$ with roots left intact.

\subsection{Sampling}

Samples were taken on 2-8 May 2012; 18-22 August 2012; and 7-9 November 2013. Six plots were sampled at each date: the 9-year, 5-year, and 3-year thinned and corresponding control plots, as described in Sect. 2.2. Within each plot three geo-referenced sampling locations were selected using Hawth's random selection tool for ArcGIS (http://www. spatialecology.com/htools). Paired soil samples were collected at each sampling location, with one sample taken under bush (Senegalia mellifera) and the other under adjacent 

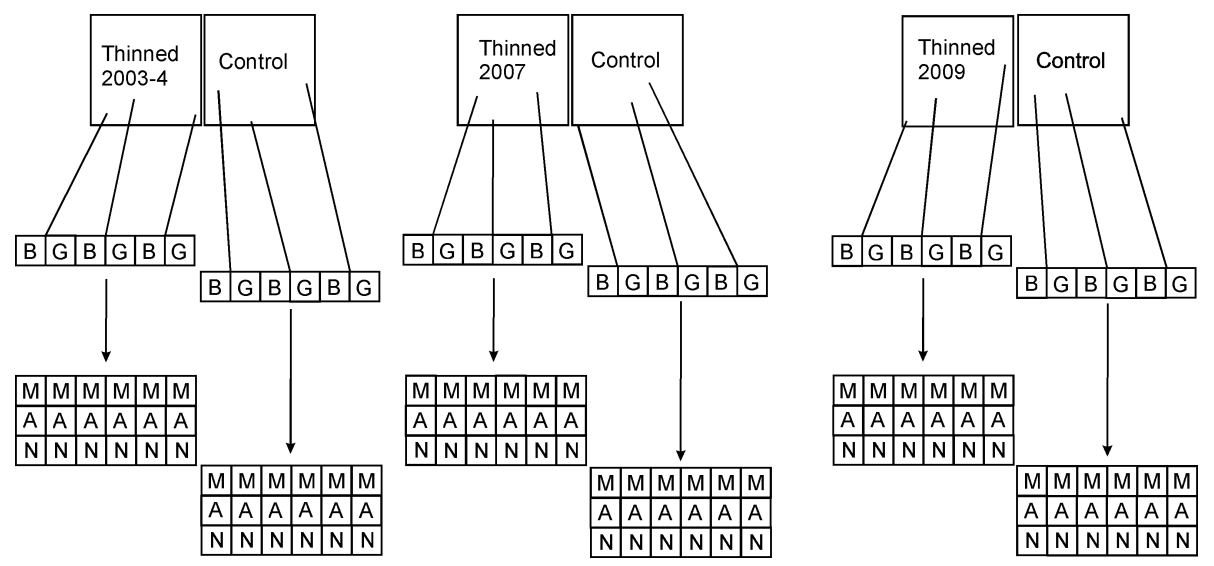

Figure 2. Experimental design. B, bush; G, grass; M, May 2012; A, August 2012; N, November 2013.

grass (Eragrostis trichophora). A free-standing bush was selected in open areas, whereas a bush within a cluster was selected in dense areas. Samples under bush were collected halfway between the trunk and the edge of the canopy. Samples were taken at the same geo-referenced sampling locations on all three sampling dates. All samples were taken at $0-15 \mathrm{~cm}$ in depth after removing surface litter. Samples were stored at $-20^{\circ} \mathrm{C}$ until analysis. A total of 108 samples were collected: 3 years of thinning $(9,5$, and 3 years $) \times 2$ treatments (thinned and control) $\times 3$ geo-referenced sampling locations $\times 2$ vegetation types (bush and grass) $\times 3$ sampling dates (May 2012, August 2012, and November 2013). The experimental design is summarized in Fig. 2.

\subsection{Soil analysis}

Soil $\mathrm{pH}$ was measured with a combination electrode after shaking $1 \mathrm{~g}$ of soil in $10 \mathrm{~mL}$ of $0.01 \mathrm{M} \mathrm{CaCl}_{2}$ for $1 \mathrm{~h}$ and letting solids settle for $15 \mathrm{~min}$. Total $\mathrm{C}$ and $\mathrm{N}$ were measured on an Elementar VarioMax CNS analyzer (Elementar Americas, Mt. Laurel, NJ, USA), using duplicate $0.5 \mathrm{~g}$ samples. No inorganic $\mathrm{C}$ was detected by reaction with acid, so the soil was noncalcareous, and total $\mathrm{C}$ equaled organic $\mathrm{C}$ (Nelson and Sommers, 1996). Soil texture was analyzed on $50 \mathrm{~g}$ samples taken from a single sampling date using the hydrometer method (Gee and Bauder, 1986).

Phospholipid fatty acids (PLFAs) were analyzed as previously described (Buyer and Sasser, 2012). Briefly, lipids were extracted and phospholipids separated by solid-phase extraction. The fatty acids present in the phospholipids were converted to fatty acid methyl esters by transesterification and analyzed by gas chromatography. Quantification was performed relative to an internal standard. Identifications were confirmed on a random subset of samples by gas chromatography-mass spectrometry. PLFAs were summed into biomarker categories as follows: Gram-positive bacteria, iso and anteiso saturated branched fatty acids; Gramnegative bacteria, monounsaturated fatty acids, and cyclo- propyl 17:0 and 19:0; actinomycetes, 10-methyl fatty acids; fungi, $18: 2 \omega 6$ cis; arbuscular mycorrhizal fungi, 16 : $1 \omega 5 \mathrm{cis}$; and protozoa, $20: 3$ and $20: 4$ fatty acids (Buyer et al., 2010).

Soil DNA was extracted and purified using $0.25 \mathrm{~g}$ samples and the PowerSoil-htp 96 Well Soil DNA Isolation Kit (MoBio Laboratories Inc., Carlsbad, CA, USA). Multiplex terminal restriction fragment length polymorphism analysis was performed for Bacteria, Archaea, and fungi as previously described (Singh et al., 2006). Briefly, bacterial, archaeal, and fungal ribosomal DNA sequences were amplified by polymerase chain reaction using fluorescent dye-labeled primers. Each PCR reaction contained 1X Amplitaq Gold ${ }^{\circledR} 360$ master mix (Thermo Fisher Scientific, Waltham, MA), $0.2 \mu \mathrm{M}$ eubacterial forward (63fVIC) and reverse (1087r) primers, $0.4 \mu \mathrm{M}$ archaeal forward (Ar3f) and reverse (Ar927rNED) primers, $0.4 \mu \mathrm{M}$ fungal forward (ITS1fFAM) and reverse (ITS4) primers, $10 \mathrm{ng}$ of template DNA, and nuclease-free water to adjust to a total reaction volume of $50 \mu \mathrm{L}$. Primer sequences are given in Singh et al. (2006). Amplification was accomplished on a Techne thermal cycler (Bibby Scientific US, Burlington, NJ, USA) according to the following protocol: initial denaturation at $95^{\circ} \mathrm{C}$ for $5 \mathrm{~min}$; $30 \mathrm{cy}-$ cles of denaturation at $95^{\circ} \mathrm{C}$ for $45 \mathrm{~s}$, annealing for $45 \mathrm{~s}$ at $55^{\circ} \mathrm{C}$, and extension at $72^{\circ} \mathrm{C}$ for $1 \mathrm{~min}$; and final extension at $72^{\circ} \mathrm{C}$ for $10 \mathrm{~min}$. The amplicons were restricted with the enzymes MspI and HhaI and purified using a Performa ${ }^{\circledR}$ DTR Edge Plate (Edge BioSystems, Gaithersberg, MD). The dyelabeled restriction fragments were analyzed on an ABI 3730 Prism Genetic Analyzer (Thermo Fisher Scientific).

\subsection{Statistical analysis}

The analysis of treatment (thinned vs. control) and vegetation (bush vs. grass) effects was accomplished using a repeated measures split-split-plot design. PLFA concentrations were analyzed in SAS (version 9.2, SAS Institute, Cary, NC, USA) with a general linear mixed model. $\mathrm{C}, \mathrm{N}, \mathrm{pH}$, and texture val- 
Table 1. Soil $\mathrm{pH}, \mathrm{C}, \mathrm{N}$, texture, and PLFA concentrations. PLFAs are reported as $\mathrm{nmol}^{-1}$ dry weight. All values are least-squares means \pm standard deviation, and values within a row with different letters are significantly different $(p=0.05)$. $N=27$ except for soil texture values, where $N=9$. The main effect of treatment (control vs. thinned) was not significant except for silt $(p=0.0007)$. The main effect of vegetation (bush vs. grass) was significant $(p=0.001)$ in all cases except for sand and clay, which were not significant. The interaction of treatment $\times$ vegetation was not significant in all cases.

\begin{tabular}{lll|ll}
\hline & \multicolumn{3}{c}{ Control } & \multicolumn{2}{c}{ Thinned } \\
\cline { 2 - 5 } & Bush & Grass & Bush & Grass \\
\hline $\mathrm{pH}$ & $5.70 \pm 0.58 \mathrm{~A}$ & $5.07 \pm 0.44 \mathrm{~B}$ & $5.32 \pm 0.59 \mathrm{AB}$ & $4.53 \pm 0.43 \mathrm{C}$ \\
Total C (\%) & $0.61 \pm 0.29 \mathrm{~A}$ & $0.38 \pm 0.08 \mathrm{~B}$ & $0.58 \pm 0.19 \mathrm{~A}$ & $0.39 \pm 0.12 \mathrm{~B}$ \\
$\mathrm{~N}(\%)$ & $0.04 \pm 0.02 \mathrm{~A}$ & $0.02 \pm 0.01 \mathrm{~B}$ & $0.04 \pm 0.01 \mathrm{~A}$ & $0.02 \pm 0.01 \mathrm{~B}$ \\
Sand (\%) & $85 \pm 2 \mathrm{~A}$ & $85 \pm 2 \mathrm{~A}$ & $85 \pm 2 \mathrm{~A}$ & $86 \pm 2 \mathrm{~A}$ \\
Silt (\%) & $7 \pm 1 \mathrm{~A}$ & $5 \pm 1 \mathrm{~B}$ & $5 \pm 1 \mathrm{~B}$ & $4 \pm 1 \mathrm{C}$ \\
Clay (\%) & $9 \pm 2 \mathrm{~A}$ & $9 \pm 2 \mathrm{~A}$ & $10 \pm 2 \mathrm{~A}$ & $10 \pm 2 \mathrm{~A}$ \\
Total PLFA & $42.68 \pm 14.23 \mathrm{~A}$ & $26.05 \pm 10.08 \mathrm{~B}$ & $47.21 \pm 16.67 \mathrm{~A}$ & $29.31 \pm 13.74 \mathrm{~B}$ \\
Gram-negative & $11.06 \pm 4.04 \mathrm{~A}$ & $5.79 \pm 2.27 \mathrm{~B}$ & $12.25 \pm 4.66 \mathrm{~A}$ & $6.08 \pm 2.37 \mathrm{~B}$ \\
Gram-positive & $10.49 \pm 3.45 \mathrm{~A}$ & $7.38 \pm 3.27 \mathrm{~B}$ & $11.07 \pm 3.51 \mathrm{~A}$ & $8.02 \pm 3.57 \mathrm{~B}$ \\
Actinomycetes & $4.74 \pm 1.30 \mathrm{~A}$ & $3.37 \pm 1.41 \mathrm{~B}$ & $4.47 \pm 1.08 \mathrm{~A}$ & $3.45 \pm 1.18 \mathrm{~B}$ \\
Fungi & $2.09 \pm 1.40 \mathrm{AB}$ & $0.85 \pm 0.80 \mathrm{~B}$ & $3.43 \pm 3.02 \mathrm{~A}$ & $1.16 \pm 1.54 \mathrm{~B}$ \\
AM fungi & $1.52 \pm 0.63 \mathrm{~A}$ & $0.82 \pm 0.38 \mathrm{~B}$ & $1.65 \pm 0.79 \mathrm{~A}$ & $0.82 \pm 0.33 \mathrm{~B}$ \\
Protozoa & $0.35 \pm 0.17 \mathrm{~A}$ & $0.10 \pm 0.09 \mathrm{~B}$ & $0.44 \pm 0.26 \mathrm{~A}$ & $0.13 \pm 0.13 \mathrm{~B}$ \\
\hline
\end{tabular}

ues were analyzed in SAS with a generalized linear mixed model utilizing a beta distribution and a logit link function (Stroup, 2015). The covariance structure was optimized for each variable and compensated for spatial (three sampling locations within each plot) and temporal (each sampling location sampled three different times) covariance. While the analysis of treatment and vegetation effects was not pseudoreplicated, as we had three pairs of thinned and control plots and compensated for covariance as described above, the analysis of recovery of thinned plots with time was inherently pseudoreplicated, as only one plot was thinned each year. Therefore, for the analysis of the effect of time since bush thinning, we calculated means for each plot and compared them without attempting to assess statistical significance.

TRFLP data were processed using the online software package T-REX (http://trex.biohpc.org/) to remove noise and align peaks (Culman et al., 2009). For both PLFA and TRFLP data, redundancy and canonical correspondence analyses were performed in CANOCO (version 5, Microcomputer Power, Ithaca, NY, USA). The proportional data were squareroot-transformed, and the length of the gradient relative to the standard deviation determined the choice between linear (redundancy analysis) and unimodal (canonical correspondence analysis) models, as advised by the CANOCO software.

\section{Results and discussion}

\subsection{Soil microbial biomass and soil properties}

\subsubsection{Treatment and vegetation effects}

The effects of treatment (thinned vs. control) and vegetation (bush vs. grass) on soil texture, $\mathrm{pH}, \mathrm{C}, \mathrm{N}$, and PLFA concentration are summarized in Table 1 . The soil was noncalcareous, so total $\mathrm{C}$ was equivalent to organic $\mathrm{C}$. There were small but statistically significant effects on soil texture, with silt higher in control plots than thinned plots and higher under bush than grass. This may be explained by wind erosion preferentially removing silt over sand and clay from thinned plots and grassy locations (Colazo and Buschiazzo, 2015).

The effect of landscape vegetation (bush vs. grass) was far greater than the effect of treatment (thinned vs. control plot) on soil chemistry and PLFA concentrations. Soils under bush had significantly higher $\mathrm{pH}, \mathrm{C}, \mathrm{N}$, and total PLFA, which corresponds to microbial biomass, than soils under grass. The concentration of each PLFA biomarker group was also greater, indicating that the biomass of the large taxonomic groups analyzed by PLFA all increased in bush compared to grass environments. While there were no statistically significant overall treatment effects on soil chemistry or PLFA concentrations, there was a statistically significant treatment effect under grass, where the $\mathrm{pH}$ was higher in control plots than in thinned plots. There were, however, significant overall treatment effects on microbial community structure (Sect. 3.2.2, below). These results are consistent with the concept of woody plants as "islands of fertility" with higher soil organic matter and nutrients than under grass (Okin et 
al., 2008), and are similar to those observed under Vachellia tortilis (Acacia tortilis) in Tunisia (Fterich et al., 2014).

\subsubsection{Sampling date effect}

The sampling date (May 2012, August 2012, November 2013) had no effect on $\mathrm{pH}, \mathrm{C}$, or N. However, there were large and statistically significant differences in PLFA concentrations between the first two samplings and the final sampling. The total PLFA concentration was 40.23, 40.35, and $28.36 \mathrm{nmol} \mathrm{g}^{-1}$ for May, August, and November samplings, respectively. Similarly, a decrease in the concentration of each and every PLFA biomarker group occurred from August 2012 to November 2013 (data not shown). Annual rainfall totaled $669 \mathrm{~mm}$ in 2012 and $223 \mathrm{~mm}$ in 2013, which likely explains the difference in microbial biomass over this time period.

\subsubsection{Chronosequence effect}

The recovery of the soil microbial biomass in the years following bush thinning was examined by comparing thinned and control plots separately for each year of thinning. We only performed this analysis for samples under grass because the purpose of bush thinning was to restore the ecosystem to one dominated by grass. In the 9-year plots, the thinned and control plots were nearly identical in total PLFA, all PLFA biomarker groups, $\mathrm{C}, \mathrm{N}$, and $\mathrm{pH}$ (Table 2). In the 5-year plots, the control plot was slightly higher than the thinned plot in $\mathrm{pH}, \mathrm{C}$, total PLFA, and most of the PLFA biomarkers. In the 3-year plots, total PLFA was much higher in the thinned plot than the control plot. PLFA biomarker groups were also higher in the thinned plot, although the amount of increase varied somewhat between biomarker groups. $\mathrm{C}$ and $\mathrm{N}$ were also higher in the thinned plot, but the $\mathrm{pH}$ was much lower. Only one thinned plot was established each year, so we cannot control for spatial variation among the different years of the chronosequence, but the general trend in the chronosequence was for soil properties, microbial biomass, and the biomass of each taxonomic group in thinned plots to become more similar to control plots with time, indicating ecosystem recovery from the disturbance created by bush thinning. These results may be explained by the death and decomposition of woody plant roots following harvesting, thus temporarily raising $\mathrm{C}, \mathrm{N}$, and microbial biomass, and by indirect effects of the regrowth of hairyflower lovegrass (Eragrostis trichophora) in the bush removal area.

\subsection{Soil microbial community structure}

\subsubsection{PLFA analysis of community structure}

PLFA analysis was also used to analyze microbial community structure. The ordination plot is presented in Fig. 3. The horizontal axis separates samples primarily according to vegetation type (grass vs. bush), while the vertical axis separates

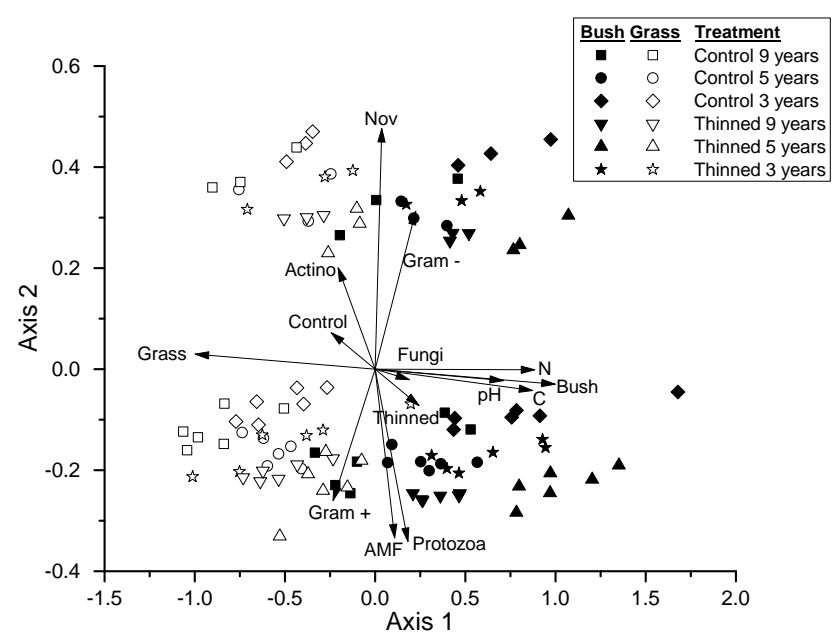

Figure 3. Redundancy analysis of soil PLFA. Vectors indicate the correlations between each factor and the axes. Very small vectors were eliminated for the sake of clarity.

primarily by sampling date. All November 2013 samples have positive axis 2 values, while all May and August 2012 samples have negative values on axis 2 . Soil samples under bush were associated with higher proportions of arbuscular mycorrhizal fungi (AMF), protozoa, and Gram-negative bacteria, while soils under grass were associated with higher proportions of actinomycetes and Gram-positive bacteria. The higher proportions of actinomycetes and Gram-positive bacteria under grass may be a response to lower carbon availability and a more oligotrophic environment, as described in Sect. 3.1.1, and are consistent with results in an agricultural system (Buyer et al., 2010). Samples taken in 2012 had higher proportions of Gram-positive bacteria, AMF, and protozoa, while samples taken in 2013 had higher proportions of actinomycetes and Gram-negative bacteria. These biomarkers should be interpreted very cautiously, as there is ample evidence in the literature to suggest that these groupings are not entirely specific (Frostegård et al., 2011).

\subsubsection{TRFLP analysis of community structure}

Soil microbial community structure was analyzed in greater detail by TRFLP. Ordinations are presented in Figs. 4, 5, and 6 for Bacteria, Archaea, and fungi. Vectors indicate correlations with treatment and environmental variables. For Bacteria and Archaea, the samples taken in November 2013 had very different TRFLP profiles than the samples taken in 2012, so they were analyzed in a separate ordination. For fungi, each sampling had different profiles, so they were all analyzed separately. Bush and grass samples were generally different in microbial community structure, while thinning and years since thinning also had some effect. Soil pH, C, and $\mathrm{N}$ also affected the TRFLP profiles. Since $\mathrm{pH}, \mathrm{C}$, and $\mathrm{N}$ were all greater in samples taken under bush than under 
Table 2. Soil pH, C, N, and PLFA mean concentrations by year of harvest under grass $(N=9)$. PLFAs are reported as nmol $\mathrm{g}^{-1} \mathrm{dry}$ weight. Means are reported without standard deviation or statistical significance as these data are pseudoreplicated.

\begin{tabular}{lrr|rr|rr}
\hline & \multicolumn{2}{c|}{ 9 years since thinning } & \multicolumn{2}{|c|}{ 5 years since thinning } & 3 years since thinning \\
\cline { 2 - 7 } & Control & Thinned & Control & Thinned & Control & Thinned \\
\hline $\mathrm{pH}$ & 4.82 & 4.69 & 5.11 & 4.87 & 5.28 & 4.02 \\
Total C (\%) & 0.34 & 0.36 & 0.42 & 0.39 & 0.35 & 0.40 \\
$\mathrm{~N}(\%)$ & 0.02 & 0.02 & 0.02 & 0.02 & 0.02 & 0.03 \\
Total PLFA & 24.3 & 24.4 & 28.55 & 27.37 & 25.3 & 36.16 \\
Gram-negative & 5.39 & 5.28 & 6.23 & 6.02 & 5.76 & 6.95 \\
Gram-positive & 6.74 & 6.94 & 8.42 & 7.56 & 6.97 & 9.55 \\
Actinomycetes & 2.82 & 3.07 & 3.77 & 3.50 & 3.51 & 3.77 \\
Fungi & 0.68 & 0.81 & 1.03 & 1.03 & 0.86 & 1.63 \\
AM fungi & 0.76 & 0.77 & 0.92 & 0.88 & 0.79 & 0.79 \\
Protozoa & 0.08 & 0.09 & 0.12 & 0.17 & 0.11 & 0.12 \\
\hline
\end{tabular}

grass, the vectors for these factors were all partially aligned with the vector for bush.

Decomposition of variance of the ordinations is presented in Table 3. Soil $\mathrm{pH}, \mathrm{C}$, and $\mathrm{N}$ explain a greater proportion of the total variance than vegetation, thinning, year of thinning, or soil texture. These results indicate that soil chemistry is more important than soil texture, vegetation type, bush thinning, or years since bush thinning in determining soil microbial community structure in this experiment. There is some shared variance between vegetation and $\mathrm{pH}, \mathrm{C}$, and $\mathrm{N}$ (data not shown), suggesting that some but not all of the effect of vegetation on the soil microbial community is through alterations in soil chemistry. This is consistent with the results presented in Table 1 which demonstrate the effects of vegetation on $\mathrm{pH}, \mathrm{C}$, and $\mathrm{N}$. $\mathrm{pH}$ is believed to be the primary driver of soil microbial community structure at continental scales (Lauber et al., 2009), while soil $\mathrm{C}$ has been identified as another factor contributing to soil microbial community structure (Fierer et al., 2007).

Bush thinning and years since bush thinning also had some effect on soil microbial community structure which was not attributed to shared variance with soil chemistry. Bush thinning may have perturbed the soil ecosystem through death and subsequent decay of roots, through changes in root exudates as the ecosystem shifted from bush to grass, or both. We interpret the effect of year of bush thinning as ecosystem recovery, but recognize that it could represent spatial variation since each thinned plot was at a different site within the Elandsvreugde farm. However, if this is a location effect, it is not entirely attributable to differences in soil $\mathrm{pH}, \mathrm{C}$, or $\mathrm{N}$, since not all variance was shared with soil chemistry. Furthermore, the thinned and control plots represent a stark contrast in terms of plant community composition and potential ecosystem function.

\subsection{Soil community recovery}

Ecosystem recovery was also assessed by calculating the Euclidean distance, in ordination space, between control and thinned plots for each year since thinning. For Bacteria in 2012, the distance between control and thinned samples under grass was 0.11 for the 9-year plots, 0.11 for the 5-year plots, and 0.49 for the 3 -year plot. For Bacteria samples taken in November 2013, the same three distances were 1.8, 0.9, and 2.0. Similarly, the analysis for Archaea indicated that the 3 -year plots had the greatest distance between control and thinned under grass in samples taken in both 2012 and 2013 (data not shown). The pattern for fungi was more complex. In May 2012 and November 2013 the 3-year plots had the greatest distance between control and thinned, while in $\mathrm{Au}-$ gust 2012 the distance was 9 years $<3$ years $<5$ years.

These results indicate that the microbial communities that were perturbed by bush thinning partially recovered over a time span of 3-9 years to a state similar to that of undisturbed grass in a bush-encroached area, which is consistent with other findings (Marchante et al., 2009). The recovery was partially obscured by seasonal variations in microbial community structure. Recovery may have been more complete for Bacteria and Archaea than fungal communities, as previously demonstrated with the response of soil microbial communities under different land-use systems to drought (de Vries et al., 2012), or else the seasonal variation had a greater obscuring effect on recovery in fungal communities than in bacterial and archaeal communities. The recovery of the 5year plot was not always intermediate between the 3 -year and 9-year plots, which may reflect unstable temporal variations in community structure during recovery or transitional microbial community structures that are dissimilar to both the 9-year and 3-year plots.

Our results demonstrate that the soil microbial community is sensitive to bush thinning but is also resilient, with some recovery over a time span of several years. The sensitivity to disturbance and the timescale of resilience are consistent 
Table 3. Decomposition of variance of TRFLP ordinations.

\begin{tabular}{lll|ll|lll}
\hline & \multicolumn{2}{c}{ Bacteria } & \multicolumn{2}{c}{ Archaea } & \multicolumn{3}{c}{ Fungi } \\
\cline { 2 - 8 } & May + Aug & Nov & May + Aug & Nov & May & Aug & Nov \\
\hline Total variance explained & $0.223^{* * *}$ & $0.369^{* * *}$ & $0.169^{* * *}$ & $0.245^{* * *}$ & $0.328^{* * *}$ & $0.326^{* * *}$ & $0.356^{* *}$ \\
\hline Total variance due to: & & & & & & & \\
Vegetation & $0.058^{* * *}$ & $0.051^{* * *}$ & $0.036^{* * *}$ & $0.030^{*}$ & $0.049^{* * *}$ & $0.049^{* * *}$ & $0.040^{* * *}$ \\
Thinning & $0.023^{* * *}$ & $0.043^{*}$ & $0.027^{* * *}$ & 0.021 & 0.025 & $0.039^{* * *}$ & $0.045^{* * *}$ \\
Year of thinning & $0.045^{* * *}$ & $0.078^{*}$ & $0.030^{*}$ & 0.046 & $0.077^{* * *}$ & $0.070^{* *}$ & $0.076^{* *}$ \\
pH, C, and N & $0.100^{* * *}$ & $0.166^{* * *}$ & $0.071^{* * *}$ & $0.103^{* * *}$ & $0.109^{* * *}$ & $0.105^{*}$ & $0.124^{* * *}$ \\
Texture & $0.055^{* *}$ & 0.107 & 0.038 & $0.080^{*}$ & 0.095 & 0.088 & 0.107 \\
\hline
\end{tabular}

Significance of results: ${ }^{*} p \leq 0.05 ;{ }^{* *} p \leq 0.01 ;{ }^{* * *} p \leq 0.005$
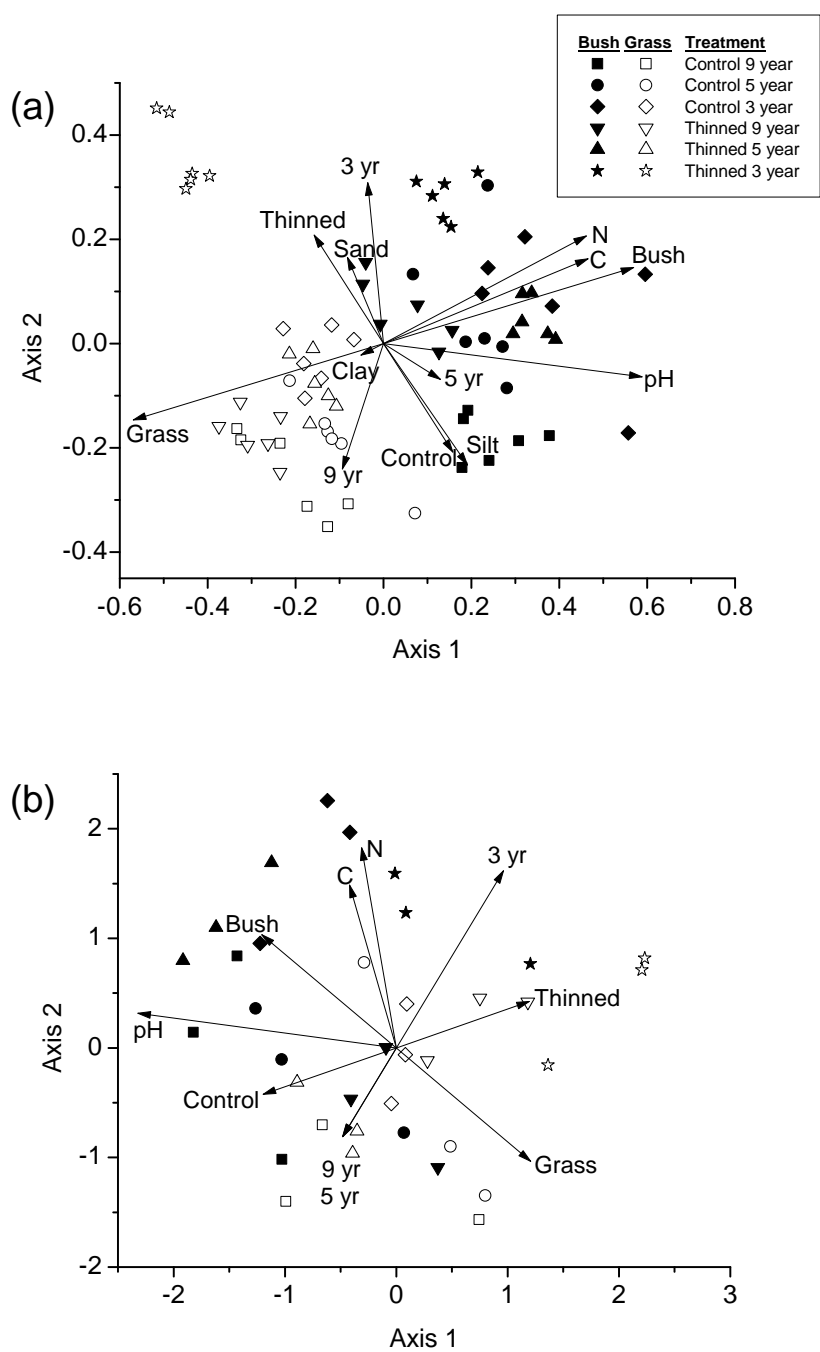

Figure 4. Redundancy analysis of bacterial TRFLP. (a) May and August 2012. (b) November 2013. Vectors indicate the correlations between each factor and the axes. Very small vectors were eliminated for the sake of clarity.
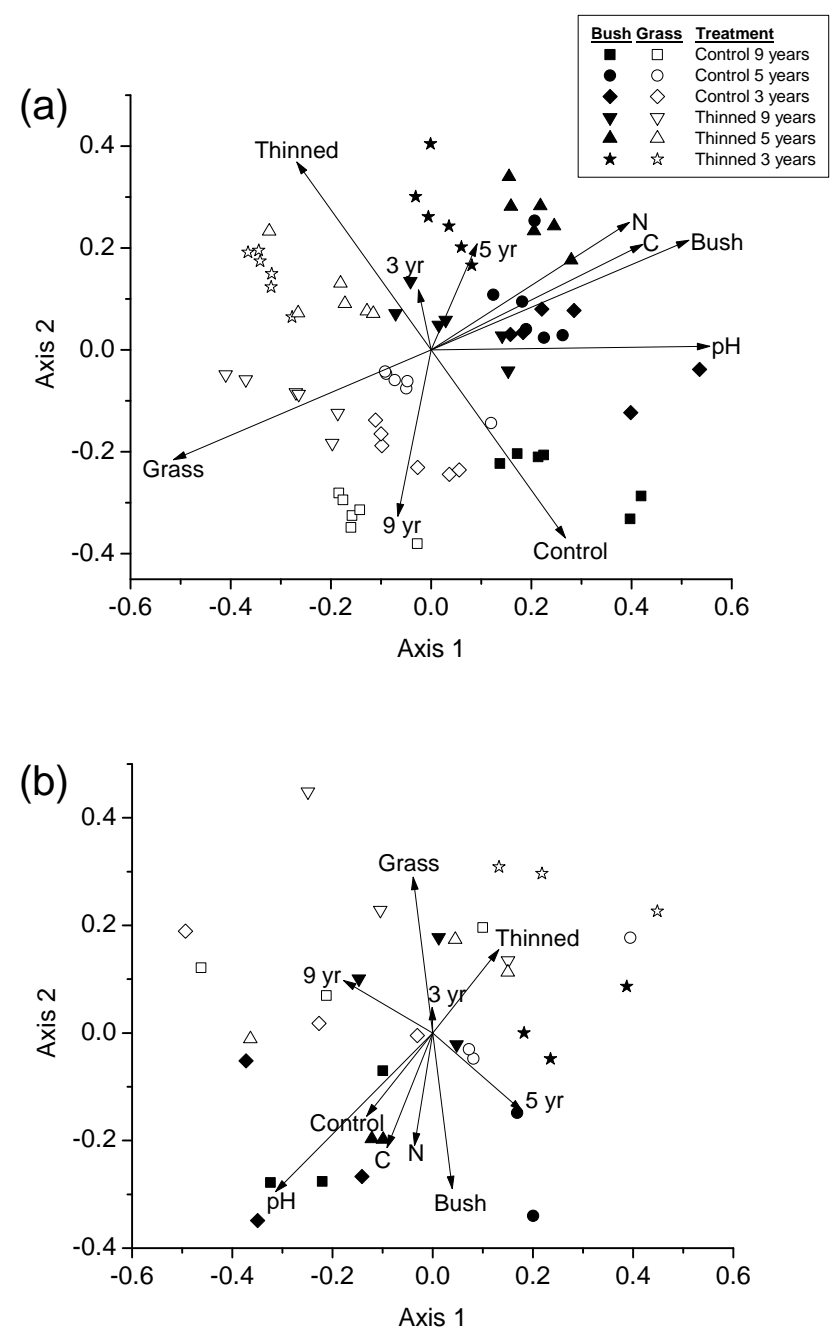

Figure 5. Redundancy analysis of archaeal TRFLP. (a) May and August 2012. (b) November 2013. Vectors indicate the correlations between each factor and the axes. Very small vectors were eliminated for the sake of clarity. 

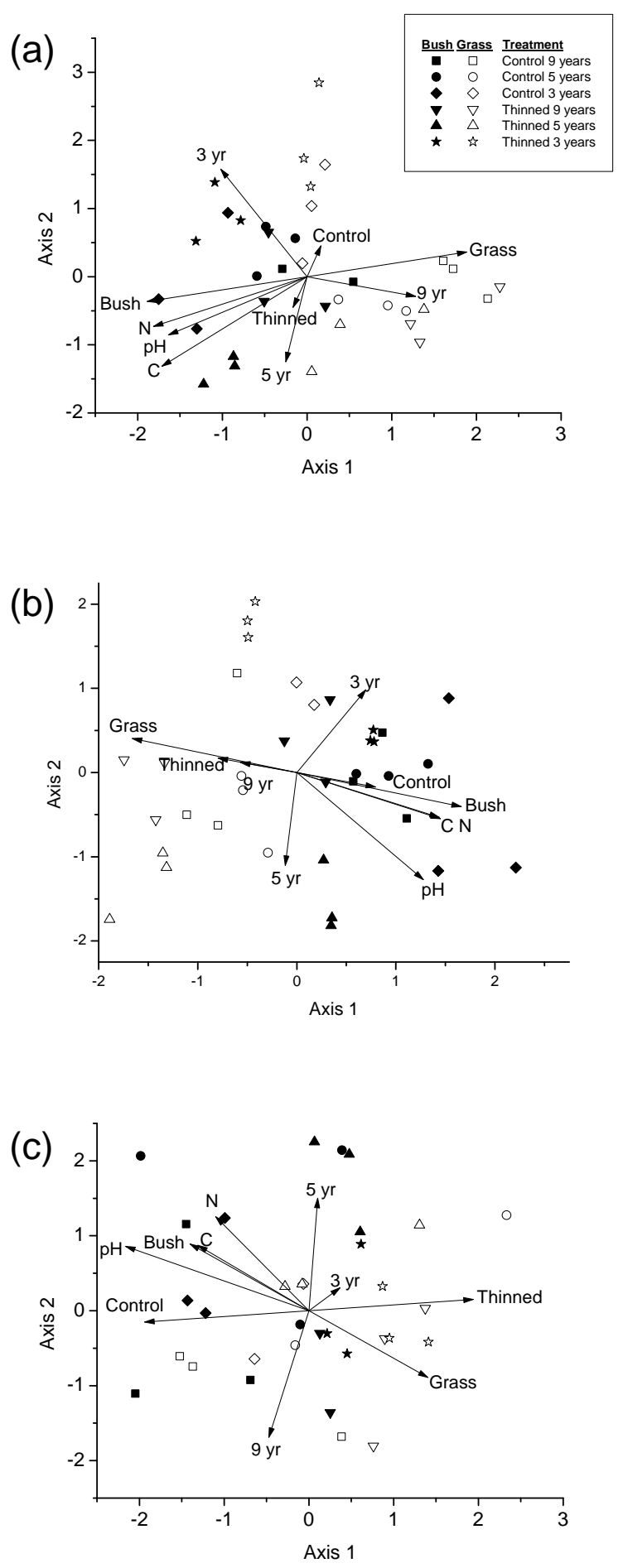

Figure 6. Canonical correspondence analysis of fungal TRFLP. (a) May 2012. (b) August 2012. (c) November 2013. Vectors indicate the correlations between each factor and the axes. Very small vectors were eliminated for the sake of clarity. with other studies (Allison and Martiny, 2008). However, a recent study (Ke et al., 2015) found no effect of plant invasion on soil microbial community structure, suggesting that certain soil communities are resistant to plant invasion and that sensitivity or resistance may depend on factors such as climate and site history as well as the specific plant species.

\subsection{Further questions}

Two other questions arise from this research that we cannot answer at this time. First, does soil ecosystem function change with the changes in microbial community biomass and structure reported here? While high levels of functional redundancy and soil microbial diversity suggest that changes in community structure may not affect function, there is evidence indicating that changes in microbial biomass and community structure may alter ecosystem processes (Reeve et al., 2010). Invasive plants have been shown to change soil ecosystem function (Weidenhamer and Callaway, 2010; Wolfe and Klironomos, 2005), which in one case was attributed to bacterial endophytes (Rout et al., 2013). The fact that Senegalia mellifera is leguminous and fixes nitrogen through symbiotic rhizobia strongly suggests that nitrogen cycling will be altered. Several soil enzyme activities were reported to be higher under the canopy of Vachellia tortilis (Acacia tortilis) than in adjacent open areas (Fterich et al., 2014).

Second, are there positive or negative feedback loops (Wardle et al., 2004) between grass and soil following bush removal? There is strong experimental evidence supporting the role of plant-soil feedback in driving plant community composition (Pendergast et al., 2013). The changes in soil chemistry and microbial communities following bush removal could promote either grass establishment (positive feedback) or bush regrowth and encroachment (negative feedback). Both soil nutrients and soil microbial communities have been shown to be involved in plant-soil feedback (Perkins and Nowak, 2013). Further work is required to answer these questions and fully assess the role of soil microbes in restoration of savannas altered by bush encroachment.

\section{Conclusions}

We found that bush thinning initially perturbs the soil ecosystem, but over 3-9 years the system recovers to a state resembling that of undisturbed grass in a bush-encroached savanna. Bush thinning may provide a way to restore both the aboveground and belowground components of bush-encroached savanna ecosystems to a more grass-dominated state.

Acknowledgements. We thank Stan Tesch, Sarah Emche, Anh Le, and Monica Hofte for technical assistance, as well as Janine Fearon, Lucia Mhuulu, Natalie Giessen, and Robert Thompson for their help with sample collection. We thank Bryan Vinyard 
for statistical advice. The sample collection was conducted under permit 1768/2013 from the Namibian Ministry of Environment and Tourism.

Edited by: F. García-Orenes

\section{References}

Allison, S. D. and Martiny, J. B. H.: Resistance, resilience, and redundancy in microbial communities, P. Natl. Acad. Sci. USA, 105, 11512-11519, doi:10.1073/pnas.0801925105, 2008.

Batten, K., Scow, K., Davies, K., and Harrison, S.: Two Invasive Plants Alter Soil Microbial Community Composition in Serpentine Grasslands, Biol. Invasions, 8, 217-230, doi:10.1007/s10530-004-3856-8, 2006.

Bond, W. J. and Midgley, G. F.: Carbon dioxide and the uneasy interactions of trees and savannah grasses, Philos. T. Roy. Soc. B, 367, 601-612, doi:10.1098/rstb.2011.0182, 2012.

Buyer, J. S. and Sasser, M.: High throughput phospholipid fatty acid analysis of soils, Appl. Soil Ecol., 61, 127-130, 2012.

Buyer, J. S., Teasdale, J. R., Roberts, D. P., Zasada, I. A., and Maul, J. E.: Factors affecting soil microbial community structure in tomato cropping systems, Soil Biol. Biochem., 42, 831-841, 2010.

Colazo, J. C. and Buschiazzo, D.: The Impact of Agriculture on Soil Texture Due to Wind Erosion, Land Degrad. Dev., 26, 6270, doi:10.1002/ldr.2297, 2015.

Culman, S., Bukowski, R., Gauch, H., Cadillo-Quiroz, H., and Buckley, D.: T-REX: software for the processing and analysis of T-RFLP data, BMC Bioinformatics, 10, 171, 2009.

de Klerk, J. N.: Bush encroachment in Namibia, Ministry of Environment and Tourism, Windhoek, Namibia, 253 pp., 2004.

de Vries, F. T., Liiri, M. E., Bjornlund, L., Bowker, M. A., Christensen, S., Setala, H. M., and Bardgett, R. D.: Land use alters the resistance and resilience of soil food webs to drought, Nature Clim. Change, 2, 276-280, 2012.

Fierer, N., Bradford, M. A., and Jackson, R. B.: Toward an ecological classification of soil bacteria, Ecology, 88, 1354-1364, doi:10.1890/05-1839, 2007.

Frostegård, A., Tunlid, A., and Bååth, E.: Use and misuse of PLFA measurements in soils, Soil Biol. Biochem., 43, 1621-1625, 2011.

Fterich, A., Mahdhi, M., and Mars, M.: The effects of Acacia tortilis subsp. Raddiana, soil texture and soil depth on soil microbial and biochemical characteristics in arid zones of tunisia, Land Degrad. Dev., 25, 143-152, doi:10.1002/ldr.1154, 2014.

Gee, G. W. and Bauder, J. W.: Particle-size analysis, in: Methods of Soil Analysis, PART 1, Soil Science Society of America, Madison, WI, 383-411, 1986.

Kambatuku, J. R., Cramer, M. D., and Ward, D.: Overlap in soil water sources of savanna woody seedlings and grasses, Ecohydrology, 6, 464-473, doi:10.1002/eco.1273, 2013.

Ke, P.-J., Miki, T., and Ding, T.-S.: The soil microbial community predicts the importance of plant traits in plant-soil feedback, New Phytologist, 206, 329-341, doi:10.1111/nph.13215, 2015.

Klass, J. R., Peters, D. P. C., Trojan, J. M., and Thomas, S. H.: Nematodes as an indicator of plant-soil interactions associated with desertification, Appl. Soil Ecol., 58, 66-77, 2012.
Lauber, C. L., Hamady, M., Knight, R., and Fierer, N.: Pyrosequencing-based assessment of soil $\mathrm{pH}$ as a predictor of soil bacterial community structure at the continental scale, Appl. Environ. Microb., 75, 5111-5120, doi:10.1128/aem.00335-09, 2009.

Lehman, R. M., Cambardella, C. A., Stott, D. E., Acosta-Martinez, V., Manter, D. K., Buyer, J. S., Maul, J. E., Smith, J. L., Collins, H. P., Halvorson, J. J., Kremer, R. J., Lundgren, J. G., Ducey, T. F., Jin, V. L., and Karlen, D. L.: Understanding and enhancing soil biological health: the solution for reversing soil degradation, Sustainability, 7, 988-1027, doi:10.3390/su7010988, 2015.

Liao, J. D. and Boutton, T. W.: Soil microbial biomass response to woody plant invasion of grassland, Soil Biol. Biochem., 40, 1207-1216, 2008.

Lynch, J. M. and Whipps, J. M.: Substrate flow in the rhizosphere, Plant Soil, 129, 1-10, 1990.

Marchante, E., Kjøller, A., Struwe, S., and Freitas, H.: Soil recovery after removal of the $\mathrm{N}_{2}$-fixing invasive Acacia longifolia: consequences for ecosystem restoration, Biol. Invasions, 11, 813-823, 2009.

Maul, J. and Drinkwater, L.: Short-term plant species impact on microbial community structure in soils with long-term agricultural history, Plant Soil, 330, 369-382, 2010.

Nelson, D. W. and Sommers, L. E.: Total Carbon, Organic Carbon, and Organic Matter, in: Methods of Soil Analysis Part 3 - Chemical Methods, edited by: Sparks, D. L., Page, A. L., Helmke, P. A., and Loeppert, R. H., SSSA Book Series, Soil Science Society of America, American Society of Agronomy, Madison, WI, 961-1010, 1996.

O'Connor, T. G., Puttick, J. R., and Hoffman, M. T.: Bush encroachment in southern Africa: changes and causes, Afr. J. Range For. Sci., 31, 67-88, doi:10.2989/10220119.2014.939996, 2014.

Okin, G. S., Mladenov, N., Wang, L., Cassel, D., Caylor, K. K., Ringrose, S., and Macko, S. A.: Spatial patterns of soil nutrients in two southern African savannas, J. Geophys. Res.-Biogeo., 113, G02011, doi:10.1029/2007jg000584, 2008.

Pendergast, T. H., Burke, D. J., and Carson, W. P.: Belowground biotic complexity drives aboveground dynamics: a test of the soil community feedback model, New Phytologist, 197, 1300-1310, doi:10.1111/nph.12105, 2013.

Perkins, L. B. and Nowak, R. S.: Native and non-native grasses generate common types of plant-soil feedbacks by altering soil nutrients and microbial communities, Oikos, 122, 199-208, doi:10.1111/j.1600-0706.2012.20592.x, 2013.

Reeve, J. R., Schadt, C. W., Carpenter-Boggs, L., Kang, S., Zhou, J., and Reganold, J. P.: Effects of soil type and farm management on soil ecological functional genes and microbial activities, ISME J., 4, 1099-1107, 2010.

Reinhart, K. O. and Callaway, R. M.: Soil biota and invasive plants, New Phytologist, 170, 445-457, doi:10.1111/j.14698137.2006.01715.x, 2006.

Riginos, C., Grace, J. B., Augustine, D. J., and Young, T. P.: Local versus landscape-scale effects of savanna trees on grasses, J. Ecol., 97, 1337-1345, 2009.

Ripple, W. J., Newsome, T. M., Wolf, C., Dirzo, R., Everatt, K. T., Galetti, M., Hayward, M. W., Kerley, G. I. H., Levi, T., Lindsey, P. A., Macdonald, D. W., Malhi, Y., Painter, L. E., Sandom, C. J., Terborgh, J., and Van Valkenburgh, B.: Collapse of 
the world's largest herbivores, Science Advances, 1, e1400103, doi:10.1126/sciadv.1400103, 2015.

Rohde, R. F. and Hoffman, M. T.: The historical ecology of Namibian rangelands: Vegetation change since 1876 in response to local and global drivers, Sci. Total Environ., 416, 276-288, doi:10.1016/j.scitotenv.2011.10.067, 2012.

Rout, M. E., Chrzanowski, T. H., Westlie, T. K., DeLuca, T. H., Callaway, R. M., and Holben, W. E.: Bacterial endophytes enhance competition by invasive plants, Am. J. Bot., 100, 17261737, doi:10.3732/ajb.1200577, 2013.

Schenck zu Schweinsberg-Mickan, M., Jörgensen, R. G., and Müller, T.: Rhizodeposition: Its contribution to microbial growth and carbon and nitrogen turnover within the rhizosphere, J. Plant Nutr. Soil Sc., 175, 750-760, doi:10.1002/jpln.201100300, 2012.

Shannon, S., Flory, S. L., and Reynolds, H.: Competitive context alters plant-soil feedback in an experimental woodland community, Oecologia, 169, 235-243, doi:10.1007/s00442-011-2195-6, 2012.

Singh, B. K., Nazaries, L., Munro, S., Anderson, I. C., and Campbell, C. D.: Use of multiplex terminal restriction fragment length polymorphism for rapid and simultaneous analysis of different components of the soil microbial community, Appl. Environ. Microbiol., 72, 7278-7285, 2006.

Singh, K., Trivedi, P., Singh, G., Singh, B., and Patra, D. D.: Effect of different leaf litters on carbon, nitrogen and microbial activities of sodic soils, Land Degrad. Dev., n/a-n/a, doi:10.1002/ldr.2313, 2014.
Smit, G. N.: An approach to tree thinning to structure southern African savannas for long-term restoration from bush encroachment, J. Environ. Manage., 71, 179-191, 2004.

Stroup, W. W.: Rethinking the analysis of non-normal data in plant and soil science, Agron. J., 107, 811-827, doi:10.2134/agronj2013.0342, 2015.

Wardle, D. A., Bardgett, R. D., Klironomos, J. N., Setälä, H., van der Putten, W. H., and Wall, D. H.: Ecological linkages between aboveground and belowground biota, Science, 304, 1629-1633, doi:10.1126/science.1094875, 2004.

Wardle, D. A.: The influence of biotic interactions on soil biodiversity, Ecol. Lett., 9, 870-886, doi:10.1111/j.14610248.2006.00931.x, 2006.

Weidenhamer, J. and Callaway, R.: Direct and indirect effects of invasive plants on soil chemistry and ecosystem function, J. Chem. Ecol., 36, 59-69, doi:10.1007/s10886-009-9735-0, 2010.

Wolfe, B. E. and Klironomos, J. N.: Breaking new ground: soil communities and exotic plant invasion, BioScience, 55, 477-487, doi:10.1641/0006-3568(2005)055[0477:bngsca]2.0.co;2, 2005.

Wu, J. P., Liu, Z. F., Sun, Y. X., Zhou, L. X., Lin, Y. B., and Fu, S. L.: Introduced Eucalyptus urophylla plantations change the composition of the soil microbial community in subtropical china, Land Degrad. Dev., 24, 400-406, doi:10.1002/ldr.2161, 2013. 